\title{
Numerical analysis for ground temperature variation
}

\author{
Raviranjan Kumar Singh ${ }^{*}$ and Ram Vinoy Sharma
}

${ }^{*}$ Correspondence:

ravi.ranjan167@gmail.com

Department of Mechanical

Engineering, N.I.T,

Jamshedpur, India

\begin{abstract}
This paper aims to predict ground temperature variation with depth for time variant ambient air temperature and solar radiation data for Jamshedpur, India. Finite difference method has been used to discretise computational domain and a scheme has been employed to determine the numerical solution. The numerical results have been validated with experimental measurement of ground temperature. The diurnal temperature variation for the hottest and the coldest days and annual variation for the year 2016 have been computed. The diurnal temperature variation is found up to $0.4 \mathrm{~m}$ depth of soil whereas annual temperature variation is up to a depth of $4 \mathrm{~m}$.
\end{abstract}

Keywords: Numerical analysis, Ground temperature, Diurnal, Annual variation

\section{Introduction}

Prediction of soil temperature has important applications such as the passive heating and cooling of buildings and agricultural greenhouses. For the design of earth-to-air heat exchangers, it is necessary to know the ground temperature at different depths. The ambient air temperature and solar radiation are the main meteorological parameters for periodic variation in thermal regime of the soil. Soni et al. (2015) presented an excellent review of research in the area of earth-air heat exchangers. Mathur et al. (2016) and (2017) studied numerically and experimentally on horizontal ground couple heat exchanger.

Chandrakant (1975) studied the ground surface temperature using the heat balance equation and considering with or without soil heat flux. Khatry et al. (1978) and Moustafa et al. (1981) presented ground temperature variation with depth taking into account the periodicity of solar radiation and atmospheric temperature for Kuwait. Bhardwaj and Bansal (1981) calculated daily and annual variations of the ground temperature for dry sunlit, wet sunlit, dry shaded, and wet shaded surface conditions at New Delhi. Mihalakakou et al. (1997) and Mihalakakou (2002) estimated ground surface temperature for bare and short-grass covered soil employing Fourier analysis and validated results by measurements in Athens and Dublin. Paul et al. (2004) performed experimentation analysis of soil temperature of forest area in Australia. Holmes et al. (2008) proposed a new model for the prediction of ground surface and depth-wise temperature difference using ground flux profile. Ozgener et al. (2013) and Chow et al. (2011) measured and predicted the temperature of soil at various depths in Izmir, Turkey, and Hong

(c) The Author(s) 2017. This article is distributed under the terms of the Creative Commons Attribution 4.0 International License (http://creativecommons.org/licenses/by/4.0/), which permits unrestricted use, distribution, and reproduction in any medium, provided you give appropriate credit to the original author(s) and the source, provide a link to the Creative Commons license, and indicate if changes were made. 
Kong, respectively. Kurylyk and Macquarrie (2014) performed analytical solution for estimation of the ground temperature at different weather conditions. Chalhoub et al. (2017) predicted the soil temperature at simple heat and moisture transfer model. $\mathrm{Hu}$ et al. (2016) estimates soil temperature, water properties, and soil thermal properties by new Fourier series analytical-based solution. Singh and Sharma (2017) performed CFD modeling of ground temperature variation.

In the present investigation, the temperature variation of soil for dry sunlit condition has been modeled for time varying boundary conditions and compared with experimental data for Jamshedpur, India.

\section{Mathematical formulation}

The ground is considered as a semi-infinite solid with one-dimensional coordinates, as shown in Fig. 1a. The variation of ground temperature follows the one-dimensional, transient heat conduction equation given by Carslaw and Jaeger (1980):

$$
\frac{\partial^{2} T(y, t)}{\partial y^{2}}=\frac{1}{\alpha} \frac{\partial T(y, t)}{\partial t} .
$$

Solution of the above equation is subjected to the first boundary condition at the ground surface given by Bhardwaj and Bansal (1981):

$$
-\left.k \frac{\partial T}{\partial y}\right|_{y=0}=h\left(T_{\mathrm{a}}-T_{y=0}\right)-\varepsilon \Delta R+\alpha_{0} S
$$

The left side of the above equation shows the conduction through the ground surface. The first term on the right-side equation shows convective heat transfer between ground surface $\left(T_{y=0}\right)$ and air $\left(T_{\mathrm{a}}\right)$. The second term is thermal radiation $(\Delta R)$ with emissivity of

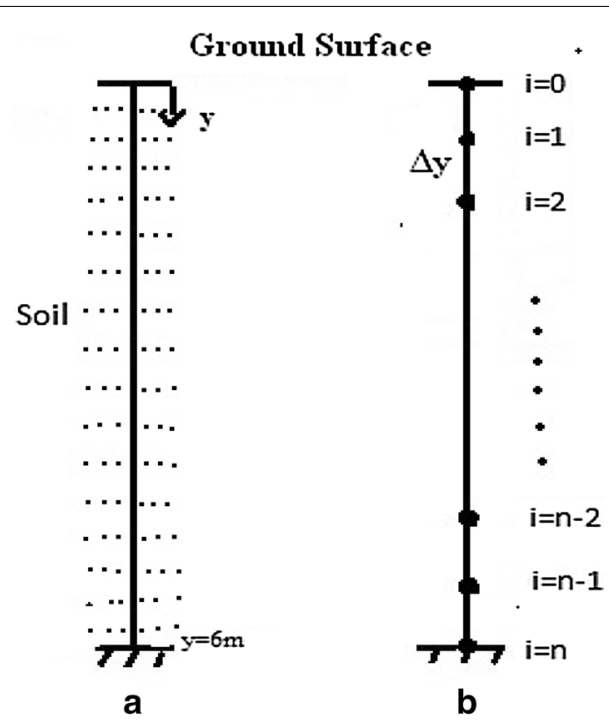

Fig. 1 a Physical model and $\mathbf{b}$ computational domain 
soil $\varepsilon$. The third term denotes solar radiation $(S)$ absorbed by the ground surface with an absorptivity of soil $\alpha_{0}$. The above equation can be written in the form of general convective heat transfer boundary condition as follows:

$$
-\left.k \frac{\partial T}{\partial y}\right|_{y=0}=h\left(T_{\mathrm{e}}-T_{y=0}\right)
$$

The temperature $T_{\mathrm{e}}$ can be expressed as follows:

$$
T_{\mathrm{e}}=T_{\mathrm{a}}+\alpha_{0} S / h-\varepsilon \Delta R / h .
$$

In Eq. (4), $h$ and $\Delta R$ are computed according to Kays and Crawford (1980). The symbol $h$ is the total heat transfer coefficient which includes convective and radiative heat transfer coefficients. The convective term depends on air velocity $(v)$ and radiative term depends on air temperature. $\Delta R$ is the thermal radiation which depends on air temperature and sky temperature given in Hillel (1980, 1982, 2004):

$$
\begin{aligned}
& h=h_{\mathrm{c}}+h_{\mathrm{r}} \\
& h_{\mathrm{c}}=2.8+3 v \\
& h_{\mathrm{r}}=4 \varepsilon \sigma T_{\mathrm{a}}^{3} \\
& T_{\text {sky }}=T_{\mathrm{a}}-12 \\
& \Delta R=\sigma\left[\left(T_{\mathrm{a}}+273.15\right)^{4}-\left(T_{\text {sky }}+273.15\right)^{4}\right] .
\end{aligned}
$$

The second boundary condition is considered as constant temperature which is the annual mean effective temperature $\left(\bar{T}_{\mathrm{e}}\right)$ :

$$
T_{y \rightarrow \infty}=\bar{T}_{\mathrm{e}} .
$$

\section{Numerical analysis}

The finite difference method has been employed for discretization of the computational domain, as shown in Fig. 1b. Forward differencing has been used for the time derivative and central differencing for space derivative of the temperature. The explicit scheme has been employed to obtain numerical solution. The discretized one-dimension conduction equation becomes

$$
T_{i}^{j+1}=r T_{i+1}^{j}+(1-2 r) T_{i}^{j}+r T_{i-1}^{j} .
$$

The stability criteria is given by Cengel and Ghajar (2011) as following:

$$
r=\frac{\Delta t \alpha}{\Delta y^{2}} \leq 0.5
$$

where $\Delta t$ and $\Delta y$ are the time step and grid size. The $\alpha$ is thermal diffusivity of the soil. 
The temperature variation of the upper surface of the ground is the first boundary condition calculated as follows:

$$
T_{0}^{j}=\frac{T_{1}^{j}+\left(\frac{h \Delta y}{k}\right) T_{\mathrm{e}}^{j}}{1+\frac{h \Delta y}{k}} .
$$

The effective temperature $\left(T_{\mathrm{e}}\right)$ is calculated with hourly data of ambient temperature, solar radiation, and wind speed data using Eq. (4). For the time variant boundary condition, $T_{e}$ is taken as mean value for each hour $(k=1,2 \ldots)$.

The second boundary condition at the end point, i.e., $y=6 \mathrm{~m}$ is considered as constant temperature which is the annual mean effective temperature $\left(\bar{T}_{\mathrm{e}}\right)$ :

$$
T_{n}^{j}=\bar{T}_{\mathrm{e}} .
$$

\section{Results and discussion}

A numerical code based on explicit scheme has been developed in $\mathrm{C}++$. The time step $\Delta t=60 \mathrm{~s}$ and grid size $\Delta y=0.01 \mathrm{~m}$ were found optimum by conducting grid sensitivity test. The upper layer of the ground consists of red soil with $20 \%$ of moisture content which is assumed to be homogeneous and its physical properties are constant as $k=1.19 \mathrm{~W} / \mathrm{mK}, \rho=2029.80 \mathrm{~kg} / \mathrm{m}^{3}, c=756.108 \mathrm{~J} / \mathrm{KgK}, \alpha_{0}=0.65$, and $\varepsilon=0.85$ measured by constant thermal analyser with $\mathrm{SH}-1$ probe. Data for ambient air temperature and solar radiation are measured and available for every minute throughout the year 2016 at Jamshedpur, India [National Institute of Wind Energy (2017)]. The hottest day for the year 2016 is 21st April, whereas the coldest day for the same year is 24th January. Hourly ambient air temperature, solar radiation, and wind speed for the hottest day and the coldest day are shown in Figs. 2, 3, and 4, respectively. The effective temperature

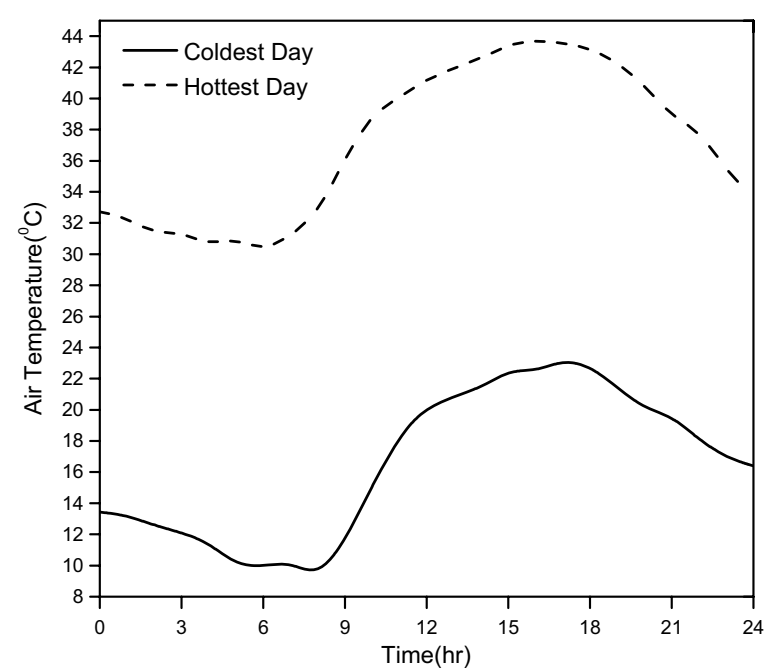

Fig. 2 Ambient air temperature for the hottest day (21st April) and the coldest day (24th January) 2016 in Jamshedpur, India 


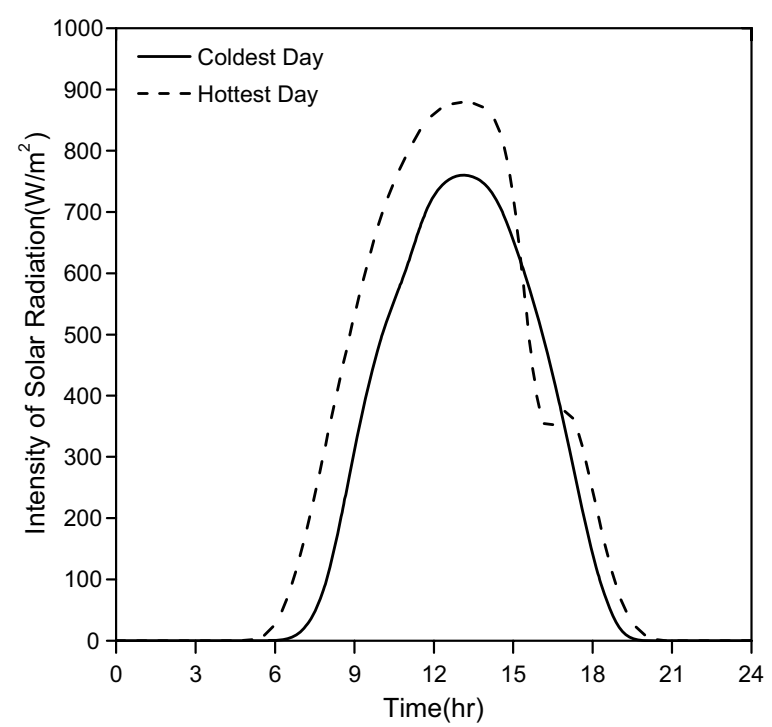

Fig. 3 Solar radiation intensity for the hottest day (21st April) and the coldest day (24th January), 2016 in Jamshedpur, India

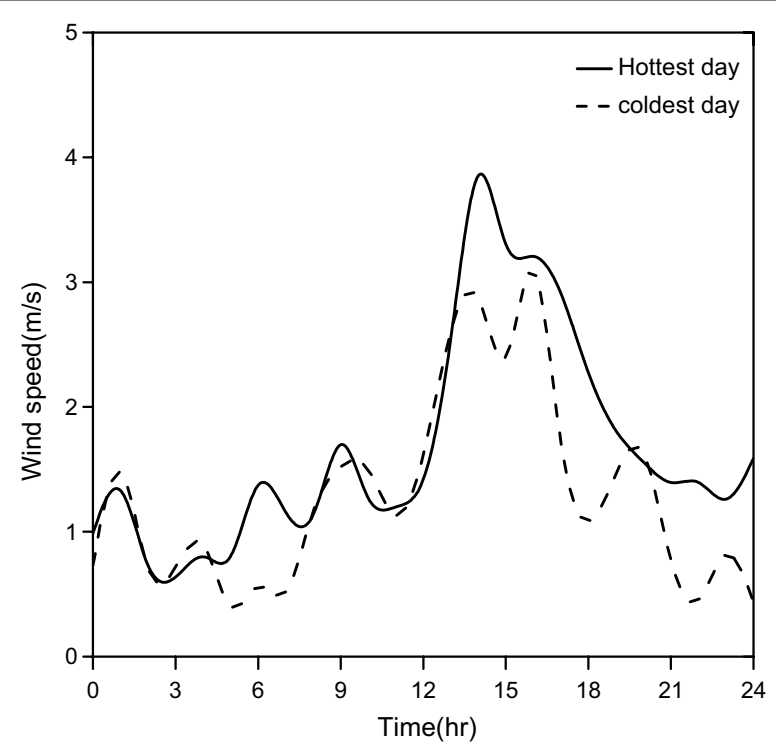

Fig. 4 Wind speed for the hottest day (21st April) and the coldest day (24th January), 2016 in Jamshedpur, India

has been computed for the coldest day, hottest day, and the year 2016 using Eq. (4) and shown in Figs. 5 and 6. The annual mean value of temperature $\left(T_{\mathrm{e}}\right)$ is $28.71{ }^{\circ} \mathrm{C}$.

For validation of the numerical scheme, soil temperature has been continuously measured every minute by thermocouples placed at the surface and at $0.5,1,2$, and $3 \mathrm{~m}$ depth of soil. Figure 7 shows the variation of temperature measured experimentally and computed numerically for 6,12 , and $21 \mathrm{~h}$ on 29 th December, 2016. There is good agreement between experimental and numerical values. 


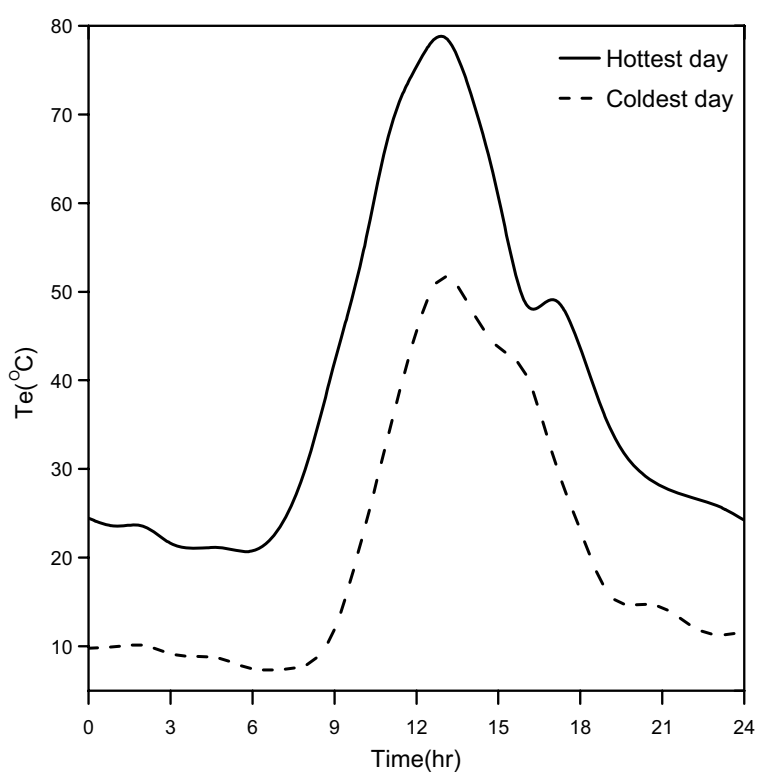

Fig. 5 Temperature, $T_{\mathrm{e}}$ for the hottest day and the coldest day

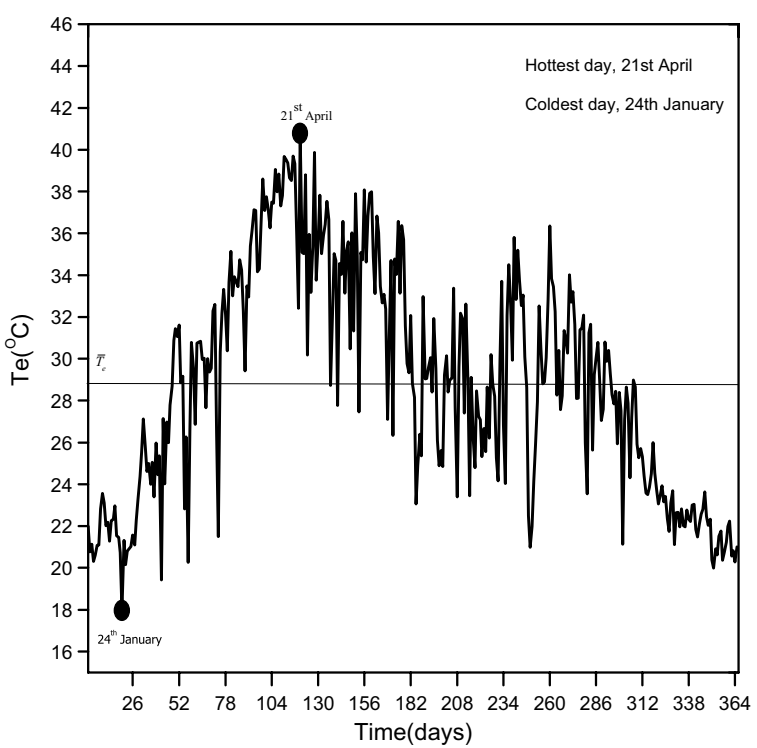

Fig. 6 Temperature, $T_{\mathrm{e}}$ for the year, 2016

Figures 8 and 9 show variation of soil temperature for the hottest and coldest day respectively. As the depth of soil increases, amplitude of temperature decreases. After a depth of $0.4 \mathrm{~m}$, there is no diurnal variation of soil temperature. 


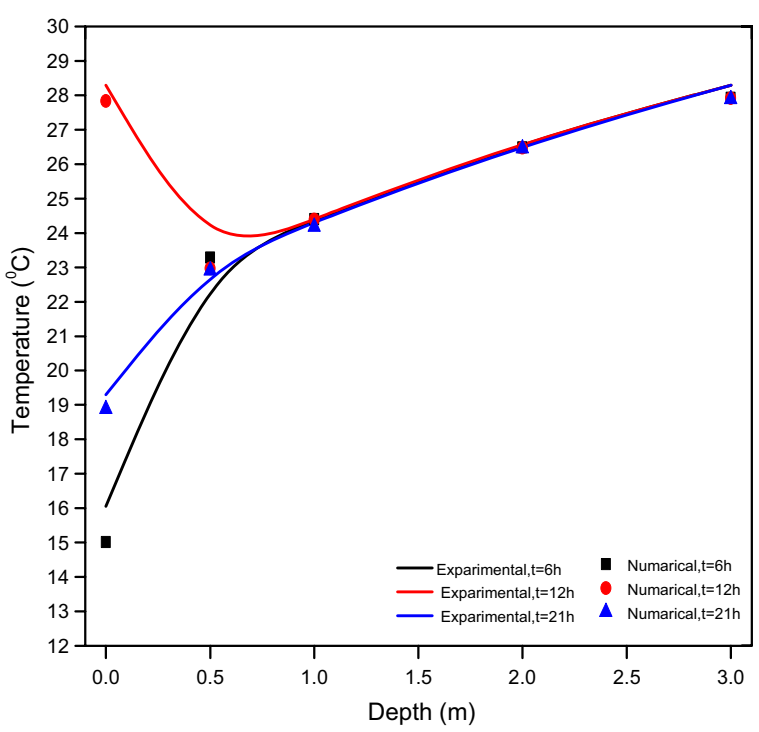

Fig. 7 Variation of soil temperature with depth for 29th December, 2016

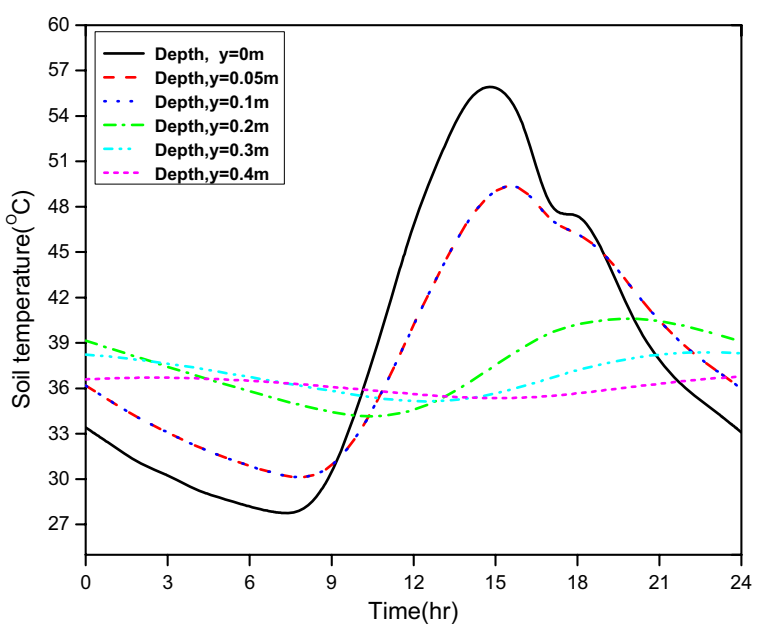

Fig. 8 Variation of soil temperature for the hottest day at various depths

Figure 10 shows annual variation of soil temperature with depth. After a depth of $4 \mathrm{~m}$, the soil temperature becomes constant. Figure 11 shows variation of soil temperature depth-wise for the hottest day and the coldest day. Diurnal variation of soil temperature is up to $0.4 \mathrm{~m}$, whereas annual variation is up to a depth of $4 \mathrm{~m}$. 


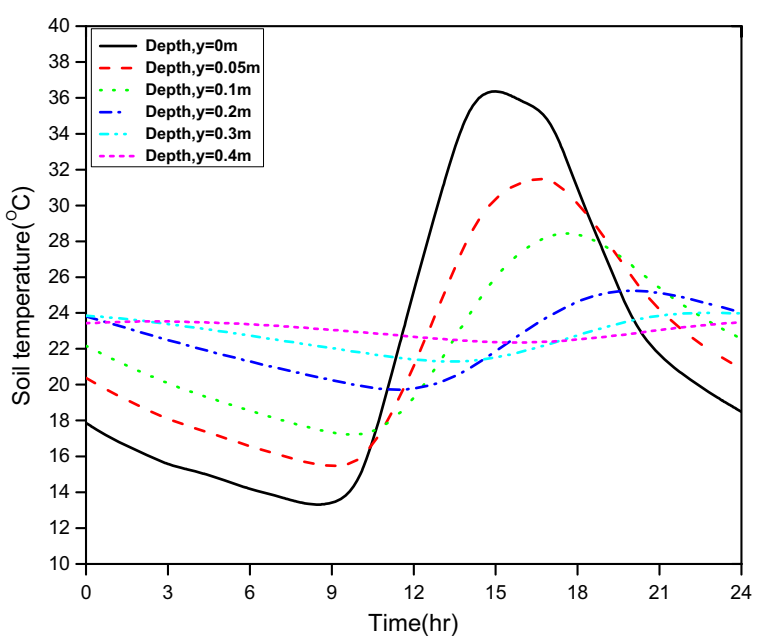

Fig. 9 Variation of soil temperature for the coldest day at various depths

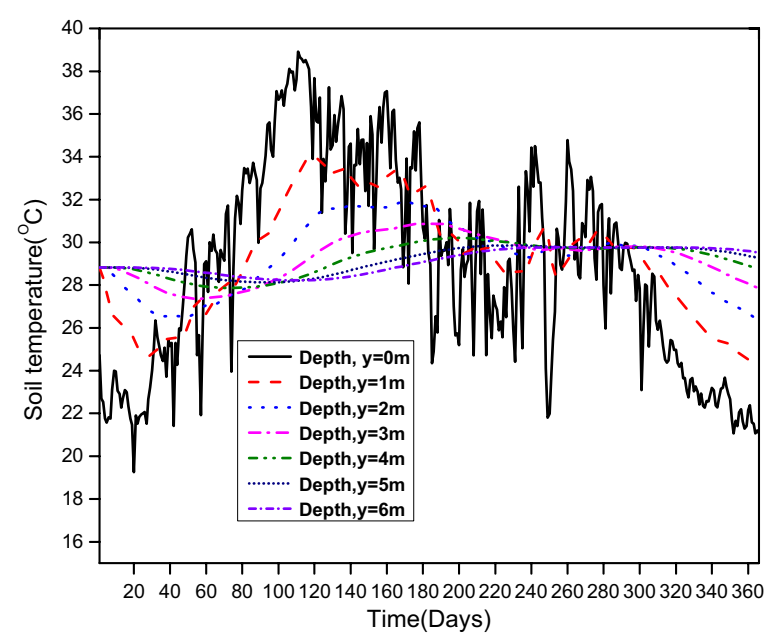

Fig. 10 Annual variation of soil temperature with depth

\section{Conclusions}

The present investigation reports the results of soil temperature variation with depth in Jamshedpur, India employing finite difference numerical method which is validated against experimental value. Diurnal variation of soil temperature is found up to depth of $0.4 \mathrm{~m}$, whereas annual variation is up to $4 \mathrm{~m}$ of depth. 


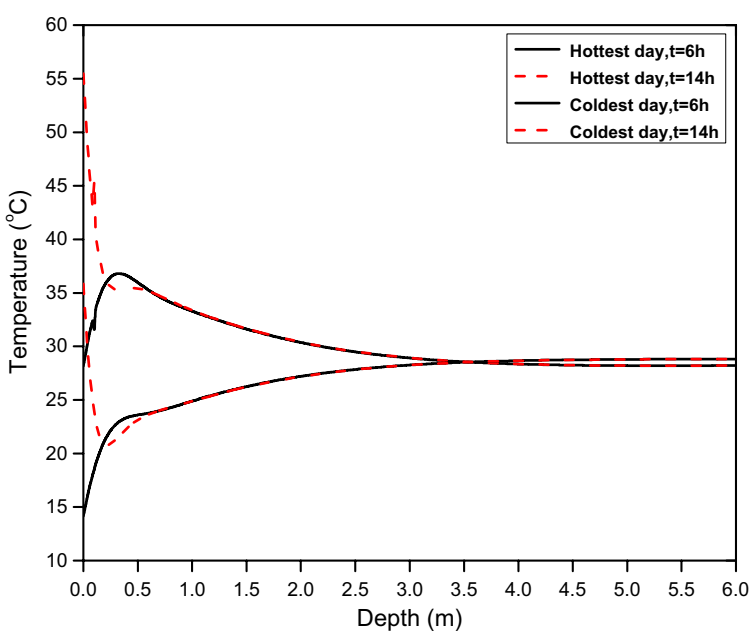

Fig. 11 Variation soil temperature with depth for the hottest and the coldest day

Authors' contributions

Both the authors are equally contribution for the articles. There are no changes in manuscript. Both authors read and approved the final manuscript.

\section{Acknowledgements}

Not applicable.

\section{Competing interests}

The authors declare that they have no competing interests.

Availability of data and materials

Not applicable.

Consent for publication

Not applicable.

Ethics approval and consent to participate

Not applicable.

\section{Funding}

Not applicable.

\section{Publisher's Note}

Springer Nature remains neutral with regard to jurisdictional claims in published maps and institutional affiliations.

Received: 20 February 2017 Accepted: 27 October 2017

Published online: 01 November 2017

\section{References}

Bhardwaj SS, Bansal NK. Temperature distribution inside ground for various surface conditions. Build Environ.

$$
\text { 1981;3:183-92. }
$$

Carslaw HS, Jaeger JC. Conduction of heat in solid. New York: Oxford Science Publication; 1980.

Cengel YA, GhajarAJ. Heat and mass transfer. New Delhi: McGraw Hill Education (India) Private Limited; 2011.

Chalhoub M, Bernier M, Coquet Y, Philippe M. A simple heat and moisture transfer model to predict ground temperature for shallow ground heat exchangers. Renew Energy. 2016. doi:10.1016/j.renene.2016.11.027.

Chandrakant MB. Numerical experiment on the computation of ground surface temperature in an atmospheric general circulation model. J Appl Metrol. 1975;14:1246-58.

Chow TT, Long H, Mok HY, Li KW. Estimation of soil temperature profile in Hong Kong from climatic variables. Energy Build. 2011;43:3568-75.

Hillel D. Fundamentals of soil physics. New York: Elsevier Academic Press; 1980.

Hillel D. Introduction to soil physics. New York: Elsevier Academic Press; 1982.

Hillel D. Introduction to environmental soil physics. New York: Elsevier Academic Press; 2004.

Holmes TRH, Owe M, De Jeu RAM, Kooi H. Estimating the soil temperature profile from a single depth observation: a simple empirical heat of low solution. Water Resour Res. 2008:44:1-11. 
Hu G, Zhao L, Wu X, Li R, Wu T, Xie C, Qiao Y, Shi J, Li W, Cheng G. New Fourier-series-based analytical solution to the conduction-convection equation to calculate soil temperature, determine soil thermal properties, or estimate water flux. Int J Heat Mass Transf. 2016;95:815-23.

Kays WM, Crawford ME. Convective heat and mass transfer. New York: McGraw-Hill Inc; 1980

Khatry AK, Sodha MS, Malik MAS. Periodic variation of ground temperature with depth. Sol Energy. 1978;20:425-7.

Kurylyk BL, Macquarrie KTB. A new analytical solution for assessing climate change impacts on subsurface temperature. Hydrol Process. 2014;3172:3161-72.

Mathur A, Suran AK, Mathur S. Numerical investigation of the performance and soil temperature recovery of an EATHE system under intermittent operations. Renew Energy. 2016;95:510-21.

Mathur A, Priyam Mathur S, Agrawal GD, Mathur J. Comparative study of straight and spiral earth air tunnel heat exchanger system operated in cooling and heating modes. Renew Energy. 2017. https://doi.org/10.1016/j. renene.2017.03.001.

Mihalakakou G. On estimation soil temperature profile. Energy Build. 2002;34:251-9.

Mihalakakou G, Santamourisand MJO, Asimalopolous FNL. On application of the energy balance equation to predict ground temperature profile. Sol Energy. 1997;60:181-90.

Moustafa S, Jarrar D, El-Mansy H, Al-Shami H, Brusewitz G. Arid soil temperature model (Technical note). Sol Energy. 1981;27:83-8.

National Institute of Wind Energy India. http://www.cwetsolar.com. Accessed on 20th Jan 2017.

Ozgener O, Ozgener L, Tester JW. A practical approach to predict soil temperature variation for geothermal (ground) heat exchanger application. Int J Heat Mass Transf. 2013;62:473-80

Paul KI, Polglase PJ, Smethurst PJ, Connell AMO, Carlyle CJ, Khanna PK. Soil temperature under forests: a simple model for predicting soil temperature under a range of forest types. Agric For Metrol. 2004:121:167-82.

Singh RK, Sharma RV. Simulation of soil temperature variation for geothermal applications. IJMET. 2017;8:167-75.

Soni KS, Pandey M, Bartaria VN. Ground coupled heat exchangers: a review and applications. Renew Sustain Energy Rev. 2015;47:83-92.

\section{Submit your manuscript to a SpringerOpen ${ }^{\circ}$ journal and benefit from:}

- Convenient online submission

Rigorous peer review

Open access: articles freely available online

- High visibility within the field

- Retaining the copyright to your article

Submit your next manuscript at $\gg$ springeropen.com 